\title{
Mechanisms Controlling the Human Immunoglobulin E Response: New Directions in the Therapy of Allergic Diseases
}

\author{
DONALD Y. M. LEUNG \\ Division of Pediatric Allergy-Immunology, National Jewish Center for Immunology and Respiratory Medicine, \\ Denver, Colorado 80206; and Department of Pediatrics, University of Colorado Health Sciences Center, \\ Denver, Colorado 80262
}

\begin{abstract}
The IgE response plays a critical role in the pathogenesis of human allergic diseases. A detailed understanding of the mechanisms underlying the regulation of $\operatorname{IgE}$ synthesis is thus important in the development of new treatments for allergic diseases. It is now well established that the induction of IgE synthesis in human B cells requires two signals. The first signal is delivered by IL-4, which induces Ig gene switching to the $\epsilon$ locus. The second signal can be delivered by a number of B-cell activators which, in combination with IL-4, cause the expression of productive $\epsilon$ mRNA transcripts and the synthesis of $\operatorname{IgE}$ protein. These second signals include contact-mediated signals delivered by $T$ cells via cognate or noncognate interactions, Epstein-Barr virus infection, hydrocortisone, and MAb to the B-cell antigen CD40. Cytokines such as IL-5 and IL-6 significantly amplify IgE synthesis, whereas interferon gamma (IFN- $\gamma$ ) inhibits IL-4-induced IgE synthesis. The production of cytokines is frequently compartmentalized to specific T-cell subsets: TH1, but not TH2, cells produce IL-2, IFN- $\gamma$ and lymphotoxin, whereas TH2 but not TH1 cells produce IL-4, IL-5, IL-6, and IL-10. These two T-cell subsets therefore produce cytokines that functionally antagonize each other, e.g. IFN- $\gamma$ inhibits proliferation of TH2 cells. Recent studies indicate that severe allergic diseases such as atopic dermatitis are associated with expansion of $\mathrm{TH} 2$ cells. These observations provide a rationale for the use of agents that interfere with IL-4 production or action, or alternatively, the use of IFN$\gamma$ in the treatment of severe allergic diseases. (Pediatr Res 33 (Suppl): S56-S62, 1993)
\end{abstract}

\section{Abbreviations}

$\mathrm{AD}$, atopic dermatitis

EBV, Epstein-Barr virus

IFN, interferon

LPR, late phase response

LPS, lipopolysaccharide

PBMC, peripheral blood mononuclear cells

r, recombinant

sIgE, surface-bound IgE response to environmental allergens. Clinically significant allergen-induced reactions are generally characterized by an IgEdependent biphasic response (1). Within minutes of exposure to allergen, mast cells bearing IgE directed to the relevant allergen become activated and release a variety of mediators, chemotactic factors, and cytokines into the local tissue. This immediate reaction is generally clinically evident within $15 \mathrm{~min}$ of allergen challenge and subsides within 30 to $90 \mathrm{~min}$ later. Three to four $\mathrm{h}$ after the immediate reaction begins to subside, there is frequently the onset of an intense inflammatory reaction, termed the "late phase response" (LPR). This is associated with the expression of leukocyte-adhesion molecules on the local vascular endothelium and the concomitant infiltration of eosinophils, neutrophils, and mononuclear cells $(2,3)$. This IgE-mediated LPR is thought to play a critical role in the pathogenesis of chronic allergic diseases. The clinical manifestations of a particular hypersensitivity reaction depend on the extent of the reaction and anatomical location of mast cell degranulation.

It has become increasingly appreciated that the IgE-mediated LPR plays an important role in the pathogenesis of chronic allergic diseases such as asthma, $\mathrm{AD}$, and allergic rhinitis. For example, it is thought that the local deposition of eosinophilderived major basic protein during the LPR contributes to the respiratory epithelial damage and lung inflammation found in asthma (4). The LPR may be sustained by infiltrating cells that bear surface-bound IgE and can therefore release cytokines and mediators on exposure to specific allergens. The importance of the LPR is further supported by the observation that the intensity of nonspecific bronchial hyperreactivity in asthmatic reactions after antigen bronchoprovocation is proportional to the intensity of the LPR (5). Clinical improvement in asthmatic symptoms after allergen immunotherapy correlates with a marked attenuation of LPR after bronchoprovocation challenge (6).

Recent studies have found a correlation between serum $\operatorname{IgE}$ levels and airway responsiveness in asthmatics and normals (7). A correlation between serum IgE level and severity of skin disease in $\mathrm{AD}$ has also been reported (8). These observations suggest that a detailed understanding of the mechanisms that control $\operatorname{lgE}$ synthesis will provide considerable insight into the pathogenesis of allergic diseases. This review focuses on recent advances in our knowledge regarding the regulation of IgE synthesis and the implications these findings may have for the development of new therapy for allergic diseases.

\section{HISTORICAL BACKGROUND}

The principal feature that distinguishes atopic individuals from nonatopic individuals is their capacity to develop a sustained $\operatorname{IgE}$

Correspondence: Donald Y. M. Leung, M.D., Ph.D., The Division of Pediatric Allergy-Immunology, The National Jewish Center for Immunology and Respiratory Medicine, 1400 Jackson St., Denver, CO 80206.

Supported in part by Grants HL-36577 and AR-41256 from the National Institutes of Health.
Studies on rodents dating back to the early 1970s have demonstrated that $\mathrm{T}$ cells play an important role in the development of IgE responses (9-11). In these studies, neonatally thymectomized rats were unable to produce IgE antibody. Whole-body irradiation or administration of immunosuppressive agents con- 
verted rats from a low-IgE response to a high-IgE responder state. This pattern of high-IgE response to allergens could be terminated by passive transfer of syngeneic $T$ cells. These studies suggested that $\mathrm{T}$ cells were also critical in suppressing $\mathrm{IgE}$ responses in low-IgE (i.e. nonatopic) responder animals.

Until recently, studies of IgE synthesis in humans have been limited because polyclonal B-cell activators that induce IgG, IgA, and IgM synthesis were not able to induce IgE synthesis by normal lymphocytes (12). Based on these observations, two possibilities were considered: I) precursor IgE B cells may be absent from the circulation of nonatopic donors, and 2) the activation of IgE-producing $\mathrm{B}$ cells may require $\mathrm{T}$-cell-derived signals not generated under IgG-inducing conditions. It was subsequently shown that $\mathbf{B}$ cells from nonatopic donors bearing the appropriate alloantigen can be induced to synthesize Ig of all isotypes, including $\operatorname{IgE}$, upon cognate interaction with selected human alloreactive (13) or autoreactive (14) helper T-cell clones. These data indicated that normal individuals possess circulating $B$ cells with the potential to differentiate into IgE-secreting cells.

The first clue that $\mathrm{T}$-cell-derived soluble factors were involved in the regulation of human $\operatorname{IgE}$ synthesis came from the observation that supernatants from $T$ cells of patients with markedly elevated serum IgE levels secrete soluble helper factor(s) that induce $\operatorname{IgE}$ but not $\operatorname{IgG}$ synthesis by B-cell-enriched populations from normal donors (15). The major breakthrough came in 1986, when Coffman and Carty (16) reported that the T-cellderived lymphokine IL-4 induced IgE production in vitro by LPS-stimulated murine B-cell blasts. The in vivo significance of IL-4 has subsequently been demonstrated in studies showing that anti-IL-4 antibody inhibits IgE responses in experimental animals $(17,18)$.

\section{REQUIREMENTS FOR INDUCTION OF IgE SYNTHESIS IN HUMANS}

In humans, IL-4 induces IgE synthesis by normal unfractionated PBMC $(19,20)$. The actual mechanism by which IL-4 contributes to the induction of IgE synthesis has been actively investigated by many laboratories but remains incompletely understood. Studies to date indicate that IL-4 acts as a crucial signal for isotype-switching to IgE. This has been shown by examination of single B cells stimulated by murine and human $\mathrm{T}$-cell clones as well as limiting dilution experiments with LPSstimulated B cells in mice (21-23). Incubation of B cells with rIL-4 induces a 1.8-kb germline C $\epsilon$ RNA transcript but not the 2.2-kb productive $\epsilon$ mRNA (24). In murine models, it has been demonstrated that $\mathrm{Ig}$ heavy chain switching is preceded by expression of the corresponding germline transcript (23). Thus, these observations are consistent with the hypothesis that IL-4 contrcis IgE isotype-switching by modulating the accessibility of the $\epsilon$ switch region to a putative common switch recombinase.

IL-4 is necessary but not sufficient for the induction of $\mathrm{IgE}$ synthesis on highly purified B cells. Addition of rIL-4 alone or in combination with a variety of other cytokines, including IL-5 and IL-6, is ineffective in inducing IgE synthesis in highly purified B-cell suspensions (25). Additional signals are required for IL-4induced IgE synthesis to occur. These second signals can be provided by $T$ cells $(26,27)$ or a variety of B-cell activators including EBV infection $(28,29), \mathrm{MAb}$ to the B-cell antigen CD40 (30-32), and hydrocortisone (33-34).

\section{T-CELL-DEPENDENT INDUCTION OF IgE SYNTHESIS}

$T$ cells can play two important roles in the induction of $\operatorname{lgE}$ synthesis. First, they provide a source of IL-4. This may account for the observation that selected, but not all, alloreactive T-cell clones can induce IgE synthesis by B cells bearing the relevant alloantigen. Second, in addition to IL-4, physical contact between $\mathrm{T}$ and $\mathrm{B}$ cells is required for IgE synthesis (26). Mixtures of $\mathrm{T}$ and $B$ cells synthesize IgE upon incubation with IL-4 only when the $\mathrm{T}$ and $\mathrm{B}$ cells are cultured in the same well, but not when they are separated by a semipermeable membrane. Furthermore, IL-4-induced IgE synthesis is strongly inhibited by MAb specific for cell adhesion molecules (26).

Although initial studies suggested that cognate interaction between $\mathrm{T}$ and $\mathrm{B}$ cells (recognition by the T-cell receptor/CD3 complex on CD4+ T cells of MHC class II antigen plus peptide on $\mathrm{B}$ cells) was required for induction of IgE synthesis, more recent studies indicate that noncognate $\mathrm{T}$ cell/B cell interaction, in which the T-cell receptor does not recognize the B-cell MHC class II antigen plus peptide complex, can also support IL-4dependent IgE synthesis (35). The antigens involved in the latter interaction are still poorly characterized. Using $\mathrm{T}$-cell clones to further study this interaction, Gascan et al. (36) found that the $T$-cell clones needed to be activated to induce IgE synthesis. Furthermore, intact activated CD4+ T-cell clones could be replaced by membranes of these cells, suggesting that an inducible membrane-associated molecule is involved in the B-cell differentiation pathway that results in IgE production. One speculation is that this molecule may represent the ligand for a B-cell activation antigen.

T-cell clones that are defective in IL-4 production can induce germline IgE transcripts via a contact-mediated signal. However, both IL- 4 and the contact-mediated signal provided by $\mathrm{T}$ cells are required to induce $2.2-\mathrm{kb}$ productive $\epsilon$-mRNA transcripts and IgE synthesis (32). The molecular mechanisms that underlie the production of productive $\epsilon$ mRNA in humans are presently a matter of speculation (reviewed in ref. 37).

\section{T-CELL-INDEPENDENT SYSTEMS OF IgE INDUCTION}

In addition to $\mathrm{T}$ cells, there is a growing list of direct (T-cellindependent) B-cell activators that can synergize with IL-4 to induce $\operatorname{IgE}$ synthesis. In this regard, it has been shown that stimulation with IL-4 and EBV induces T-cell-independent IgE synthesis in human B cells $(28,29)$. IgE production in this system was shown to be due to de novo induction of isotype switching rather than expansion of a precommitted sIgE + B-cell population, which has undergone $\mathrm{C} \epsilon$ switching in vivo, because slgEnegative B-cell precursors could be stimulated by EBV and IL-4 to produce IgE. IgE-secreting $B$ cells obtained by activation with EBV and IL-4 contained both the $1.8-\mathrm{kb}$ germline $\mathrm{C} \epsilon$ RNA transcript and the 2.2-kb productive $\epsilon$ mRNA (29).

More recently, several investigators have reported that highly purified B cells costimulated with rIL-4 and various MAb to CD40 synthesize high levels of $\operatorname{IgE}$ antibody $(30,31)$. Stimulation of $\mathrm{B}$ cells from nonatopic donors with anti-CD40 MAb, in the absence of IL-4, results in a small increase in IgG synthesis but no IgE or IgM synthesis. When both anti-CD40 and rIL-4 are added, IgG production increases slightly; however, large amounts of $\operatorname{IgE}$ are synthesized.

CD40 stimulation alone, however, can enhance IgE production from in vivo driven IgE-producing cells from atopic patients (31). In this regard, rIL-4 has been demonstrated to up-regulate CD40 expression on B cells. B cells from atopic donors have been found to have increased expression of CD40 on their cell surface (38). Thus, the capacity of anti-CD40 alone to enhance IgE production by B cells from atopic donors may reflect in vivo exposure to IL-4. These data suggest that the signals delivered for IgE production by IL- 4 and CD 40 stimulation could serve as a model for the activation of IgE synthesis seen in vivo in human allergic disease.

The natural ligand of CD40 is unknown. Molecular cloning has demonstrated that the CD40 gene is closely related to receptors for nerve growth factor (39) and tumor necrosis factor- $\alpha$ (40). The various anti-CD40 MAb have not been able to induce calcium mobilization (41). In the presence of primary B-cell activators such as phorbol esters or anti-IgM, however, antiCD40 MAb can deliver a strong progression signal to resting B cells $(42,43)$. Thus, it has been suggested that CD40 may be 
involved in the regulation of B-cell activation and growth. One possibility that has been suggested is that $T$ cells express a ligand for CD40 on activation. This would implicate CD40 in noncognate, contact-dependent $T$-cell interactions.

Hydrocortisone has been found to up-regulate IL-4-dependent IgE synthesis by normal unfractionated mononuclear cells (33). These observations have been extended to demonstrate that sIgE- B cells from nonatopic donors can be induced to synthesize IgE when incubated with a combination of hydrocortisone and rIL-4 (34). The mechanisms by which hydrocortisone synergizes with IL-4 are unknown. However, these in vitro observations provide an immunologic basis for the in vivo studies, which demonstrate that atopic individuals frequently have an increase in serum IgE during the first $2 \mathrm{wk}$ after systemic steroid therapy.

Taken together, these data indicate that the second signal(s) required for $\mathrm{IgE}$ production can be delivered to B cells through different activation pathways. In particular, it has been shown that anti-CD40 MAb and CD4+ T-cell clones act with rIL-4 to induce $\operatorname{IgE}$ switching in purified $\mathrm{B}$ cells via different signaling pathways (32). The exact mechanisms by which diverse signals such as T cells, EBV, hydrocortisone, and anti-CD40 stimulate IgE synthesis in the presence of rIL-4 remain to be elucidated. It is possible, however, that these different pathways will share the ability to activate switch recombination in B cells that have been incubated with IL-4 to render the $\mathrm{C} \epsilon$ locus accessible.

\section{MODULATION OF IgE SYNTHESIS BY CYTOKINES}

Although IL-4 is critical for the induction of IgE synthesis, other cytokines have been found to modulate IL-4-induced IgE synthesis. In particular, IL-5, a nonisotype-specific B-cell growth factor (44), and IL-6, a B-cell differentiation factor, up-regulate IgE synthesis induced by IL-4 in PBMC (25). Indeed, endogenous IL-6 seems to be critical for IL-4-induced IgE synthesis in PBMC, inasmuch as anti-IL-6 antibody strongly inhibits the production of $\mathrm{IgE}$ in such cultures. In contrast, IL-1 and tumor necrosis factor- $\alpha$ have no effect on this response. Although some laboratories have reported that IL-2 enhances IL-4-induced IgE synthesis, others have found no significant effect.

IFN- $\gamma$, IFN- $\alpha$, and transforming growth factor- $\beta$ have been reported to suppress IL-4-induced IgE synthesis in experimental animals and humans (45-48). Of these three cytokines, IFN- $\gamma$ has been studied most extensively for its capacity to inhibit IgE synthesis in vitro and in vivo. The capacity of human and mouse $T$-cell clones to induce IgE synthesis has been found to be directly correlated with the ratio of secreted IL- 4 to IFN- $\gamma$ (47). IFN- $\gamma$ also antagonizes the effects of IL-4 in other systems, e.g. IFN- $\gamma$ has been reported to inhibit the IL-4-dependent induction of CD23 on B cells (49). Of particular interest is the finding that the production of IFN- $\gamma$ is down-regulated by IL-4 $(27,50)$. The capacity of IL-4 to induce IgE synthesis thus may reflect not only its ability to induce germline $\epsilon$ transcripts but also its ability to suppress the production of IFN- $\gamma$, a potent antagonist of IL-4 action.

The mechanism by which IFN- $\gamma$ inhibits IgE synthesis remains unknown. It has been reported that IFN- $\gamma$ inhibits the expression of $\epsilon$ germline transcripts in murine B cells stimulated with IL-4 and LPS (51). However, no inhibition of $\epsilon$ germline transcripts has been observed when IFN- $\gamma$ is added to purified human B cells stimulated with IL-4 (24). These observations suggest that activation of $\epsilon$ germline transcription and switch recombination are separate events. IFN- $\gamma$ may thus prevent recombination events without affecting the expression of $\epsilon$-mRNA transcripts. It has also been observed that stimulation of $\operatorname{IgE}$ synthesis induced by IL- 4 and anti-CD40 is not inhibited by IFN- $\gamma(31$, 32). IFN- $\gamma$ can, however, inhibit IgE synthesis induced by IL-4 and EBV (28) and can inhibit $\epsilon$ germline transcription when $B$ cells are stimulated with IL-4 in the presence of T cells (24). These data suggest that the capacity of IFN- $\gamma$ to inhibit IgE synthesis may depend on the pathway of B-cell activation. Fur- thermore, the possibility remains that IFN- $\gamma$ may act indirectly on $T$ cells to either down-regulate IL-4 production or induce the production of another cytokine that can inhibit IgE synthesis.

\section{COMPARTMENTALIZATION OF T CELLS BY CYTOKINE PROFILES}

In 1986, Mosmann et al. (52) described two distinct types of cloned mouse helper T-cell lines that were defined primarily by differences in the pattern of lymphokines synthesized. TH1 but not TH2 cells produce IL- 2 , IFN- $\gamma$, and lymphotoxin, whereas TH 2 but not TH1 cells produce IL-4, IL-5, IL-6, and IL-10 (53). IL-3 and granulocyte-macrophage colony stimulating factor are secreted by both types. TH1 and $\mathrm{TH} 2$ cells have been reported to remain well defined and functionally stable, at least in tissue culture.

Although both $\mathrm{TH} 1$ and $\mathrm{TH} 2$ cells can enhance B-cell proliferation, $\mathrm{TH} 2$ but not $\mathrm{TH} 1$ cells support B-cell antibody secretion (53). This may be due to the ability of TH1 cells to kill B cells, probably via IFN- $\gamma$ and lymphotoxin production, as well as the capacity of TH2 but not TH1 cells to produce IL-6, a B-cell differentiation factor. The primary function of $\mathrm{TH} 1$ cells is thought to be involvement in mediating delayed-type hypersensitivity responses (54).

The selective expansion of $\mathrm{TH} 2$ cells is thought to play a critical role in inducing IgE synthesis because of the selective ability of IL- 4 secreted by TH 2 cells to induce Ig gene switching to the $\epsilon$ locus (22-24). The cytokines secreted by these two helper cells appear to be more important than the cell type providing the help because TH1 cells can provide help for IgE production in the presence of exogenous rIL-4 and anti-IFN- $\gamma$ (53). In addition to stimulating IgE synthesis via IL-4, TH2 cells also enhance two other features of allergic responses. First, at least in mice, IL-3 and IL-4 are mast cell growth factors (55). Second, in humans and in mice, IL-5 induces the proliferation and differentiation of eosinophils both in vitro and in vivo $(20,56)$.

The mechanisms that regulate the differentiation of resting $\mathrm{T}$ cells into TH1 versus $\mathrm{TH} 2$ cytokine secretion phenotypes are not well understood. In mice, the cytokine environment has been identified as one important influence on the type of helper $\mathrm{T}$ cell generated. Gajewski et al. (57) have shown that TH1 cells are preferentially generated when CD4+ cells are cloned in the presence of IFN- $\gamma$. Conversely, Swain et al. (58) have reported that the presence of IL-4 during helper T-cell effector generation in vitro enhances the development of IL-4- and IL-5-secreting effectors while suppressing the development of effectors that can secrete IL-2 and IFN- $\gamma$.

Cytokines also influence the activation and growth of fully differentiated TH1 and $\mathrm{TH} 2$ cells. IFN- $\gamma$ inhibits the proliferation of TH2-cell lines responding to either IL-2 or IL-4 but does not inhibit the proliferation of TH1-cell lines (59). IL-10 inhibits the synthesis of cytokines by TH1 cells but not TH 2 cells (60). It is also likely that the nature of the antigen, as well as the antigen-presenting cell itself, can regulate the differentiation of helper $\mathrm{T}$ cells. In this regard, Finkelman et al. (48) recently presented evidence supporting the notion that antigen-presenting cells, by secreting IFN- $\alpha$ early in the course of an immune response, e.g. to an infectious agent, can down-regulate the $\operatorname{IgE}$ response but enhance IgG2a synthesis in mice.

\section{RELEVANCE OF TH1/TH2 CELLS TO HUMAN ALLERGIC DISEASE}

Although many mouse $\mathrm{T}$-cell clones can be classified into either the TH1 - or the TH2-cell pattern, a number of laboratories have shown that other cytokine secretion patterns can be observed in mouse T-cell clones $(61,62)$. Such patterns include the TH0-cell pattern, in which IL-2, IFN- $\gamma$, IL-4, and IL-5 are present. Other intermediate patterns have been seen, particularly when unimmunized mice are used as donors for $\mathrm{T}$ cell cloning. 
Normal unimmunized mouse spleen T cells, termed "THp cells," when first stimulated produce high levels of IL-2 but not other $T$-cell cytokines $(63,64)$. Repeated antigen stimulation, however, results in the ability to produce other cytokines, such as IL-4 and IFN- $\gamma$. These experiments provide evidence for the hypothesis that there are precursor $\mathrm{T}$ cells that differentiate into $\mathrm{TH} 1, \mathrm{TH} 2$, and THO cells.

These results also fit well with data obtained with many human T-cell clones. In this regard, most alloreactive or phytohemagglutinin-induced human T-cell clones derived from the peripheral blood of normal donors have intermediate patterns of cytokine production that do not fit clearly into TH1 or TH2 cells. However, $\mathrm{T}$ cells isolated from diseased tissues or peripheral blood of patients with active disease have been found to exhibit TH1- or TH2-like cytokine profiles. Thus, CD4+ T cells isolated from thyroid glands of patients with autoimmune thyroiditis, when cloned by limiting dilution with phytohemagglutinin, develop into T-cell clones that produce IFN- $\gamma$ but not IL-4. In contrast, most $\mathrm{T}$ cells infiltrating the conjunctiva of patients with vernal conjunctivitis develop into $\mathrm{T}$-cell clones that produce high levels of IL-4 but not IFN- $\gamma(65)$. Using in situ hybridization, Kay et al. (66) have also reported increased mRNA expression of IL-3, IL-4, IL-5, and granulocyte-macrophage colony stimulating factor but no IFN- $\gamma$ mRNA expression in skin biopsies of allergeninduced late-phase reactions in atopic subjects.

The nature of the antigenic stimulus may play an important role in influencing $T$-cell differentiation. In this regard, the majority of allergen-specific T-cell clones from atopic individuals produce high levels of IL- 4 and IL- 5 but low levels of IFN- $\gamma$ after antigen stimulation $(67,68)$. In contrast, virtually all $T$-cell clones specific for bacterial components, e.g. tetanus toxoid established from the same donors, produce high levels of IL-2 and IFN- $\gamma(68)$. Del Prete et al. (69) also derived 60 T-cell clones specific for purified protein derivative of Mycobacterium tuberculosis and 69 T-cell clones specific for Toxocara canis from two healthy individuals. Their data indicate that the great majority of purified protein derivative-specific T-cell clones secreted IL-2 and IFN- $\gamma$ but no or limited amounts of IL-4 and IL-5. In contrast, most $T$. canis-specific T-cell clones secreted IL-4 and IL- 5 but no or limited amounts of IL- 2 and IFN- $\gamma$.

The potential importance of a dysregulation of IL-4 and IFN$\gamma$ production in allergic diseases is further supported by immunologic characterization of PBMC from patients with $A D$ and markedly elevated serum IgE levels. B cells and monocytes from AD patients express increased levels of the CD23 (low-affinity IgE receptor) surface antigen (70). Furthermore, peripheral blood $\mathrm{B}$ cells from $\mathrm{AD}$ patients spontaneously produce high levels of $\operatorname{IgE}(13)$. Because IL-4 plays an important role in the induction of IgE synthesis as well as CD23 expression on B cells (49) and monocytes (71), these observations suggest that $\mathrm{AD}$ is associated with increased secretion of IL-4 in vivo. In this regard, several investigators have reported that the increased spontaneous production of $\operatorname{IgE}$ in vitro by lymphocytes from $\mathrm{AD}$ patients can be inhibited by the addition of anti-IL-4 $(72,73)$. Furthermore, T cells from selected $\mathrm{AD}$ patients have been found to spontaneously secrete increased amounts of IL-4 (73).

PBMC from AD patients have also been found to have a decreased capacity to produce IFN- $\gamma$ in response to a number of stimuli $(73,74)$. A significant correlation has been reported between IFN- $\gamma$ generation in vitro and IgE serum concentrations in vivo in $\mathrm{AD}$ (74). Spontaneous $\mathrm{IgE}$ production by $\mathrm{PBMC}$ from $\mathrm{AD}$ patients can also be suppressed by the addition of IFN- $\gamma$ (73). Taken together, these data suggest that an imbalance of IL4 and IFN- $\gamma$ production may account for many of the immunologic features found in patients with severe allergic disease and elevated IgE levels.

\section{IMMUNOMODULATORY STRATEGIES IN CONTROL OF} ALLERGIC DISEASES

The current management of allergic diseases is generally directed toward relief of the clinical symptoms present at any given time. Because patients with allergic diseases manifest abnormalities in immune regulation, there has been much interest in the development of therapy directed toward correcting their immune dysfunction or restoring the differential balance of cytokines involved in the allergic inflammatory response. As already discussed, IL-4 plays a critical role in the induction of IgE synthesis. In this regard, antibodies to IL-4 or its receptor completely block IgE responses in experimental animals $(17,18)$. As humanized antibodies directed to such specificities and cytokine or cytokine receptor antagonists become available, the safety and efficacy of such therapy may be tested. The recent cloning and expression of a recombinant extracellular domain of the human IL-4 receptor that inhibits the in vitro biologic effects of IL-4 on $T$ and $B$ lymphocytes also offers a novel therapeutic approach to counteracting the effects of IL-4 (75).

Several experimental immunomodulators have recently been studied in clinical trials for the treatment of AD. In a study by Leung et al. (76), thymopentin, a synthetic pentapeptide that promotes differentiation of thymocytes and T-cell production of IL- 2 and IFN- $\gamma$, was found in a double-blind, placebo-controlled study of 100 patients to cause significant relief of pruritus and erythema due to AD. As already discussed, IFN- $\gamma$ suppresses the in vitro IgE response. Several investigators have therefore assessed the in vivo effect of IFN- $\gamma$ in patients with hyper IgE syndrome and AD. King et al. (77) reported that two patients with hyper IgE syndrome had a decrease in serum IgE levels while receiving IFN- $\gamma$ by s.c. injection. In an open-label study, Boguniewicz et al. (78) presented preliminary data in 23 patients with chronic $\mathrm{AD}$ suggesting a marked reduction in clinical severity after therapy with rIFN- $\gamma$. In this study, there was significant inhibition of spontaneous IgE synthesis by circulating lymphocytes while patients were on therapy. However, no effects on serum IgE levels were noted, even in patients on long-term maintenance therapy. These results suggest that the clinical efficacy of IFN- $\gamma$ in $\mathrm{AD}$ is not due to an effect on serum IgE levels.

More recently, in a double-blind, placebo-controlled trial, rIFN- $\gamma$ therapy was found to be significantly more effective than placebo in reducing the clinical severity of $\mathrm{AD}(79)$. During this trial, AD patients treated with IFN- $\gamma$ had a significant reduction in numbers of circulating eosinophils. These observations are intriguing because IL-4 and IL-5 production compartmentalizes to the TH2-cell subpopulation. Recent studies have demonstrated that allergen-specific $\mathrm{T}$ cells isolated from the $\mathrm{AD}$ skin lesion produce high levels of IL-4 but no or low levels of IFN- $\gamma$, i.e. a TH2 cytokine phenotype (80). Furthermore, in mice, it has been shown that IFN- $\gamma$ inhibits the proliferation of TH 2 cells (59). Taken together, these observations suggest that the administration of rIFN- $\gamma$ in vivo may act by inhibiting TH2-cell expansion and therefore result in a reduction of $\mathrm{IgE}$ synthesis and eosinophil differentiation by indirectly inhibiting IL-4 and IL-5 production. Further studies are needed to test this hypothesis by examining the effects of IFN- $\gamma$ on human TH 2 cells.

Other immunomodulatory approaches to the treatment of allergic diseases have also been used. These include the use of cyclosporine, a drug that reduces IgE production and inflammation possibly by inhibiting cytokine production by $T$ cells (81). Intravenous immune globulin, given at high doses, has been reported to have immunomodulatory effects that include the inhibition of $\operatorname{IgE}$ synthesis and reduction of allergen-induced immediate skin test reactivity in patients with severe asthma (82). In the future, these approaches to therapy as well as other immunologic approaches to the treatment of allergic diseases are likely to arise as we better understand the mechanisms that underlie allergic diseases. If further controlled studies confirm the safety and efficacy of these immunologic treatment approaches, these may represent exciting alternatives to be used in patients who are resistant to currently available therapy. 


\section{REFERENCES}

1. Dolovich J, Hargreave FE, Chalmers R, Shier KJ, Gauldie J, Bienenstock J 1973 Late cutaneous allergic responses in isolated IgE-dependent reactions. J Allergy Clin Immunol 52:38-46

2. Klein LM, Lavker RM, Matis WL, Murphy GF 1989 Degranulation of human mast cells induces an endothelial antigen central to leukocyte adhesion. Proc Natl Acad Sci USA 86:8972-8976

3. Leung DYM, Pober JS, Cotran RS 1991 Expression of an endothelial leukocyte adhesion molecule (ELAM-1) in elicited late phase allergic skin reactions. J Clin Invest 87:1805-1810

4. Gleich GJ 1982 The late phase of the immunoglobulin E-mediated reaction: a link between anaphylaxis and common allergic disease? J Allergy Clin Immunol 70:160-169

5. Cartier A, Thomson NC, Frith PA, Roberts R, Hargreave FE 1982 Allergeninduced increase in bronchial responsiveness to histamine: relationship to the late asthmatic response and change in airway caliber. J Allergy Clin Immunol 70:170-177

6. Warner JO, Soothill JF, Price JF, Hey EN 1978 Controlled trial of hyposensitization with Dermatophagoides pteronyssinus antigen in children with asthma. Lancet 2:912-917

7. Sears MR, Burrows B, Flannery EM, Herbison GP, Hewitt CJ, Holdaway MD 1991 Relation between airway responsiveness and serum IgE in children with asthma and in apparently normal children. N Engl J Med 325:10671071

8. Jones HE, Inouye JC, McGerity JL, Lewis CW 1975 Atopic disease and serum immunoglobulin E. Br J Dermatol 92:17-25

9. Okumura K, Tada T 1971 Regulation of homocytotropic antibody formation in the rat. III. Effect of thymectomy and splenectomy. J Immunol 106:10191025

10. Tada T, Taniguchi M, Okumura K 1971 Regulation of homocytotropic antibody formation in the rat. II. Effect of $\mathrm{X}$ irradiation. $\mathrm{J}$ Immunol 106:1012-1018

11. Taniguchi M, Tada T 1971 Regulation of homocytotropic antibody formation in the rat. IV. Effects of various immunosuppressive drugs. J Immunol 107:579-585

12. Leung DYM, Geha RS 1986 Control of $\mathrm{IgE}$ synthesis in man. J Clin Immunol 6:273-283

13. Umetsu D, Leung DYM, Jabara H, Geha RS 1985 Differential requirements of $\mathrm{B}$ cells from normal and allergic subjects for the induction of IgE synthesis by an alloreactive T cell clone. J Exp Med 162:202-214

14. Leung DYM, Young MC, Geha RS 1986 Induction of IgG and IgE synthesis in normal B cells by autoreactive T cell clones. J Immunol 136:2851-2855

15. Saryan JA, Leung DYM, Geha RS 1983 Induction of human IgE synthesis by a factor derived from T cells with hyper IgE states. J Immunol 130:242-247

16. Coffman RL, Carty J 1986 A T cell activity that enhances polyclonal IgE production and its inhibition by interferon- $\gamma$. J Immunol 136:949-954

17. Finkelman FD, Katona IM, Urban JF, Snapper CM, Ohara J, Paul WE 1986 Suppression of in vivo polyclonal IgE responses by monoclonal antibody to the lymphokine B-cell stimulatory factor 1. Proc Natl Acad Sci USA 83:9675-9678

18. Finkelman FD, Katona IM, Urban JF, Holmes J, Ohara J, Tung AS, Sample JV, Paul WE 1988 IL-4 is required to generate and sustain in vivo IgE responses. J Immunol 141:2335-2341

19. Pène J, Rousset F, Brière F, Chrétien I, Paliard X, Banchereau J, Spits H, deVries JE 1988 IgE production by normal human lymphocytes is induced by interleukin 4 and suppressed by interferon- $\gamma$ and $-\alpha$ and prostaglandin E2. Proc Natl Acad Sci USA 85:6880-6884

20. Jabara HH, Ackerman SJ, Arai K, Vercelli D, Yokota T, Abrams J, Umetsu DT, deVries JE, Leung DYM, Geha RS 1988 Induction of interleukin-4dependent eosinophil differentiation by supernatants of a human helper $T$ cell clone. J Clin Immunol 8:437-446

21. Lebman DA, Coffman RL 1988 Interleukin-4 causes isotype switching to IgE in T cell-stimulated clonal B cell cultures. J Exp Med 168:853-862

22. Gascan H, Gauchat J-F, Roncarolo M-G, Yssel H, Spits H, de Vries JE 1991 Human B cell clones can be induced to proliferate and to switch to IgE and IgG4 synthesis by interleukin 4 and a signal provided by activated CD4+ T cell clones. J Exp Med 173:747-750

23. Rothman P, Chen Y-Y, Lutzker S, Li SC, Stewart V, Coffman R, Alt FW 1990 Structure and expression of germline immunoglobulin heavy-chain $\epsilon$ transcripts: interleukin-4 plus lipopolysaccharide-directed switching to $\mathrm{C}_{\epsilon}$. Mol Cell Biol 10:1672-1680

24. Gauchat J-F, Lebman DA, Coffman RL, Gascan H, de Vries JE 1990 Structure and expression of germline $\epsilon$ transcripts in human B cells induced by interleukin 4 to switch to IgE production. J Exp Med 172:463-473

25. Vercelli D, Jabara HH, Arai K, Yokota T, Geha RS 1989 Endogenous IL-6 plays an obligatory role in IL-4 induced human IgE synthesis. Eur J Immunol 19:1419-1425

26. Vercelli D, Jabara HH, Arai K, Geha RS 1989 Induction of human IgE synthesis requires interleukin 4 and T-B cell interaction involving the T cell receptor/CD3 complex and MHC class II antigens. J Exp Med 169:12951299

27. Vercelli D, Jabara HH, Lauener RP, Geha RS 1990 IL-4 inhibits the synthesis of IFN- $\gamma$ and induces the synthesis of $\mathrm{IgE}$ in human mixed lymphocyte cultures. J Immunol 144:570-573

28. Thyphronitis G, Tsokos GC, June CH, Levine AD, Finkelman FD 1989 IgE secretion by Epstein-Barr virus-infected purified human B lymphocytes is stimulated by interleukin 4 and suppressed by interferon- $\gamma$. Proc Natl Acad Sci USA 86:5580-5584

29. Jabara HH, Schneider LC, Shapira SK, Alfieri C, Moody CT, Kieff E, Geha RS, Vercelli D 1990 Induction of germ-line and mature CE transcripts in human B cells stimulated with rIL-4 and EBV. J Immunol 145:3468-3473

30. Jabara HH, Fu SM, Geha RS, Vercelli D 1990 CD40 and IgE: synergism between anti-CD40 MAb and IL-4 in the induction of $\mathrm{IgE}$ synthesis by highly purified human B cells. J Exp Med 172:1861-1864

31. Ke Z, Clark EA, Saxon A 1991 CD40 stimulation provides an IFN- $\gamma$ independent and IL4-dependent differentiation signal directly to human B cells for IgE production. J Immunol 146:1836-1842

32. Gascan H, Gauchat J-F, Aversa G, van Vlasselaer P, de Vries JE 1991 AntiCD40 monoclonal antibodies or CD4+ T cell clones and IL-4 induce IgG4 and IgE switching in purified human B cells via different signaling pathways. J Immunol 147:8-13

33. Wu CY, Sarfati M, Heusser C, Fournier S, Rubio-Trujillo M, Peleman R, Delespesse G 1991 Glucocorticoids increase the synthesis of immunoglobulin E by interleukin 4-stimulated human lymphocytes. J.Clin Invest 87:870877

34. Jabara HH, Ahern DJ, Vercelli D, Geha RS 1991 Hydrocortisone and IL-4 induce IgE isotype switching in human B cells. J Immunol 147:1557-1560

35. Parronchi P, Tiri A, Macchia D, de Carli M, Biswas P, Simonelli C, Maggi E, Del Prete G, Ricci M, Romagnani S 1990 Noncognate contact-dependent B cell activation can promote IL-4 dependent in vitro human IgE synthesis. $\mathrm{J}$ Immunol 144:2102-2108

36. Gascan H, Gauchat J-F, de Waal Malefyt R, Schneider P, Yssel H, de Vries JE 1991 Regulation of human IgE synthesis. Clin Exp Allergy 21(suppl 1):162-166

37. Vercelli D, Geha RS 1991 Regulation of IgE synthesis in humans: a tale of two signals. J Allergy Clin Immunol 88:285-297

38. Brodie C, Renz H, Bradley KL, Leung DYM, Gelfand EW 1992 Anti-CD40 stimulates IgE production in peripheral blood mononuclear cells from patients with atopic dermatitis. J Allergy Clin Immunol 89:720A(abstr)

39. Braesch-Andersen S, Pauli S, Koho H, Nika H, Aspenstrom P, Perlmann P 1989 Biochemical characteristics and partial amino acid sequence of the receptor-like human B cell and carcinoma antigen CDw40. J Immunol 142:562-567

40. Smith CA, Davis T, Anderson D, Solam L, Beckman P, Jerzy R, Dower SK, Cosman D, Goodwin RG 1990 A receptor for tumor necrosis factor defines an unusual family of cellular and viral proteins. Science 248:1019-1024

41. Gruber MF, Bjorndahl JM, Nakamura S, Fu SM 1989 Anti-CD45 inhibition of human B cell proliferation depends on the nature of activation signals and the state of B cell activation. J Immunol 142:144-152

42. Ledbetter JA, Shu G, Gallagher M, Clark EA 1987 Augmentation of normal and malignant $\mathrm{B}$ cell proliferation by a monoclonal antibody to the $\mathrm{B}$ cellspecific antigen Bp50 (CDw40). J Immunol 138:788-794

43. Paulie S, Rosen A, Ehlin-Henriksson B, Braesch-Andersen S, Jakobson E, Koho H, Perlmann P 1989 The human B-lymphocyte and carcinoma antigen, $\mathrm{CDw} 40$, is a phosphoprotein involved in growth signal transduction. J Immunol 142:590-595

44. Pène J, Rousset F, Brière F, Chrétien I, Wideman J, Bonnefoy JY, de Vries JE 1989 Interleukin- 5 enhances interleukin-4 induced IgE production by normal human B cells: the role of soluble CD23 antigen. Eur J Immunol 18:929-935

45. Snapper CM, Paul WE 1987 Interferon- $\gamma$ and B cell stimulatory factor-1 reciprocally regulate Ig isotype production. Science 236:944-947

46. Pène J, Rousset F, Brière F, Chrétien I, Bonnefoy JY, Spits H, Yokota T, Arai N, Arai KI, Banchreau J, de Vries JE 1988 IgE production by human B cells is induced by IL-4 and suppressed by interferons $\gamma, \alpha$ and prostaglandin E2. Proc Natl Acad Sci USA 85:6880-6884

47. Del Prete GF, Maggi E, Parronchi P, Chrétien I, Tiri A, Macchia D, Ricci M, Banchereau J, deVries JE, Romagnani S $1988 \mathrm{IL}-4$ is an essential factor for the IgE synthesis induced in vitro by human cell clones and their supernatants. J Immunol 140:4193-4198

48. Finkelman FD, Svetic A, Gresser I, Snapper C, Holmes J, Trotta PP, Katona IM, Gause WC 1991 Regulation by interferon- $\alpha$ of immunoglobulin isotype selection and lymphokine production in mice. J Exp Med 174:1179-1188

49. DeFrance T, Aubry J, Rousset F, Vanhervliet B, Bonnefoy JY, Arai N, Takebe Y, Yokota T, Lee F, Arai K, de Vries J, Banchereau J 1987 Human recombinant interleukin-4 induces Fc $\epsilon$ receptors (CD23) on B lymphocytes. Proc Natl Acad Sci USA 165:1459-1467

50. Peleman R, Wu J, Fargeas C, Delespesse G 1989 Recombinant interleukin 4 suppresses the production of interferon $\gamma$ by human mononuclear cells. J Exp Med 170:1751-1756

51. Berton MT, Uhr JW, Vitetta ES 1989 Synthesis of germ-line $\gamma 1$ immunoglobulin heavy-chain transcripts in resting B cells: induction by interleukin- 4 and inhibition by interferon- $\gamma$. Proc Natl Acad Sci USA 86:2829-2833

52. Mosmann TR, Cherwinski H, Bond MW, Giedlin MH, Coffman R 1986 Two types of murine helper $\mathrm{T}$ cell clones. I. Definition according to profiles of lymphokine activities and secretory proteins. J Immunol 136:2348-2357

53. Mosmann TR, Coffman RL 1989 TH1 and TH2 cells: different patterns of lymphokine secretion lead to different functional properties. Annu Rev Immunol 7:145-173

54. Cher DJ, Mosmann TR 1987 Two types of murine helper T cell clones. 2 Delayed-type hypersensitivity is mediated by $\mathrm{THI}$ clones. J Immunol 138:3688-3694

55. Mosmann TR, Bond MW, Coffman RL, Ohara J, Paul WE 1986 T cell and 
mast cell lines respond to B cell stimulatory factor-1. Proc Natl Acad Sci USA 83:5654-5658

56. Yamaguchi Y, Suda T, Suda J, Eguchi M, Miura Y, Harada N, Tominaga A, Takatsu K 1988 Purified interleukin 5 supports the terminal differentiation and proliferation of murine eosinophilic precursors. J Exp Med 167:43-56

57. Gajewski TF, Joyce J, Fitch FW 1989 Anti-proliferative effect of IFN- $\gamma$ in immune regulation. J Immunol 143:15-22

58. Swain SL, Weinberg AD, English M, Huston G 1990 Il-4 directs the development of Th2-like helper effectors. J Immunol 145:3796-3806

59. Gajewski TF, Fitch FW 1988 Anti-proliferative effect of IFN- $\gamma$ in immune regulation. I. IFN- $\gamma$ inhibits the proliferation of Th2 but not Th1 murine helper T cell clones. J Immunol 140:4245-4252

60. Fiorentino DF, Bond MW, Mosmann TR 1989 Two types of mouse helper T cell. IV. Th2 clones secrete a factor that inhibits cytokine production by $\mathrm{Th} 1$ clones. J Exp Med 170:2081-2095

61. Street NE, Shumacher JH, Fong AT, Bass H, Fiorentino DF, Leverah JA, Mosmann TR 1990 Heterogeneity of mouse helper T cells: evidence from bulk cultures and limiting dilution cloning for precursors of Th1 and Th2 cells. J Immunol 144:1629-1639

62. Firestein GS, Roder WD, Laxer JA, Townsend KS, Weaver CT, Horn JT, Linton HJ, Torbett BE, Glasebrook A 1989 A new murine CD4+ T cell subset with an unrestricted cytokine profile. J Immunol 143:518-525

63. Swain SL, McKenzie DT, Weinberg AD, Hancock W 1988 Characterization of $T$ helper 1 and 2 cell subsets in normal mice. Helper $T$ cells responsible for IL-4 and IL-5 production are present as precursors that require priming before they develop into lymphokine-secreting cells. J Immunol 141:34453455

64. Swain SL, Weinberg AD, English M 1990 CD4+ T cell subsets: lymphokine secretion of memory cells and of effector cells which develop from precursors in vitro. J Immunol 144:1788-1799

65. Maggi E, Biswas P, Del Prete GF, Parronchi P, Macchia D, Simonelli C, Emmi L, De Carli M, Tiri A, Ricci M, Romagnani S 1991 Accumulation of Th2like helper $\mathrm{T}$ cells in the conjunctiva of patients with vernal conjunctivitis. J Immunol 146:1169-1174

66. Kay AB, Ying S, Varney V, Gaga M, Durham SR, Moqbel R, Wardlaw AJ, Hamid Q 1991 Messenger RNA expression of the cytokine gene cluster, interleukin 3 (IL-3), IL-4, IL-5, and granulocyte/macrophage colony-stimulating factor, in allergen-induced late-phase cutaneous reactions in atopic subjects. J Exp Med 173:775-778

67. Wierenga EA, Snoek M, deGroot C, Chrétien I, Bos JD, Jansen HM, Kapsenberg ML 1990 Evidence for compartmentalization of functional subsets of CD4+ T-lymphocytes in atopic patients. J Immunol 144:4651-4656

68. Parronchi P, Macchia D, Piccinni M-P, Biswas P, Simonelli C, Maggi E, Ricci $M$, Ansari AA, Romagnani S 1991 Allergen- and bacterial antigen-specific $T$-cell clone established from atopic donors show a different profile of cytokine production. Proc Natl Acad Sci USA 88:4538-4542

69. Del Prete GF, De Carli M, Mastromauro C, Biagiotti R, Macchia D, Falagiani $\mathrm{P}$, Ricci M, Romagnani S 1991 Purified protein derivative of $M y$ cobacterium tuberculosis and excretory-secretory antigen(s) of Toxocara canis expand in vitro human $\mathrm{T}$ cells with stable and opposite (Type $1 \mathrm{~T}$ helper or Type $2 \mathrm{~T}$ helper) profile of cytokine production. J Clin Invest 88:346-350

70. Vercelli D, Jabara HH, Lee BW, Woodland N, Geha RS, Leung DYM 1988 Human recombinant interleukin 4 induces $F c \in R_{2} / C D 23$ on normal human monocytes. J Exp Med 167:1406-1416

71. Polla BS, Ezekowitz RAB, Leung DYM 1992 Monocytes from patients with severe atopic dermatitis are primed for superoxide production. J Allergy Clin Immunol 89:545-551

72. Vollenweider S, Saurat J-H, Rocken M, Hauser C 1991 Evidence suggesting involvement of interleukin-4 (IL-4) production in spontaneous in vitro IgE synthesis in patients with atopic dermatitis. J Allergy Clin Immunol 87:10881095

73. Rousset F, Robert J, Andary M, Bonnin J-P, Souillet G, Chrétien I, Brière F, Pène J, deVries JE 1991 Shifts in interleukin-4 and interferon- $\gamma$ production by $T$ cells of patients with elevated serum $\operatorname{IgE}$ levels and the modulatory effects of these lymphokines on spontaneous IgE synthesis. J Allergy Clin Immunol 87:58-69

74. Reinhold U, Pawelec G, Wehrmann W, Herold M, Wernet P, Kreysel HW 1988 Immunoglobulin $\mathrm{E}$ and immunoglobulin $\mathrm{G}$ subclass distribution in vivo and relationship to in vitro generation of interferon-gamma and neopterin in patients with severe atopic dermatitis. Int Arch Allergy Appl Immunol 87:120-126

75. Garrone P, Djossou O, Galizzi J-P, Banchereau J 1991 A recombinant extracellular domain of the human interleukin 4 receptor inhibits the biological effects of interleukin 4 on $\mathrm{T}$ and B lymphocytes. Eur J Immunol 21:13651369

76. Leung DYM, Hirsch RL, Schneider L, Moody C, Takaoka R, Li SH, Meyerson LA, Mariam SG, Goldstein G, Hanifin JM 1990 Thymopentin therapy reduces the clinical severity of atopic dermatitis. J Allergy Clin Immunol 85:927-934

77. King CL, Gallin JI, Malech HL, Abramson SL, Nutman TB 1989 Regulation of immunoglobulin production in hyperimmunoglobulin $E$ recurrent-infection syndrome by interferon- $\gamma$. Proc Natl Acad Sci USA 86:1085-1089

78. Boguniewicz M, Jaffe HS, Izu A, Sullivan MJ, York D, Geha RS, Leung DYM 1990 Recombinant gamma interferon in treatment of patients with atopic dermatitis and elevated IgE levels. Am J Med 88:365-370

79. Schneider LC, Hanifin J, Cooper $\mathrm{K}$, Boguniewicz M, Milgrom $H$, Jaffe HS, Izu AE, Bucalo LR, Leung DYM 1991 Recombinant interferon gamma therapy reduces the clinical severity of atopic dermatitis. J Allergy Clin Immunol 87:383A(abstr)

80. van der Heijden FL, Wierenga EA, Bos JD, Kapsenberg ML 1991 High frequency of IL-4-producing CD4+ allergen-specific T lymphocytes in atopic dermatitis lesional skin. J Invest Dermatol 97:389-394

81. Van Joost T, Stolz E, Heule F 1987 Efficacy of low-dose cyclosporine in severe atopic skin disease. Arch Dermatol 123:166-167

82. Mazer BD, Gelfand EW 1991 An open-label study of high-dose intravenous immunoglobulin in severe childhood asthma. J Allergy Clin Immunol $87: 976-983$

\section{FLOOR DISCUSSION}

Dr. Levinson: A recounting of your work and Dr. Geha's work that deals with IgE-binding factors was conspicuously absent from your excellent review. For those of us who grew up during the era of IgE-binding factors with your work and Ishizaka's work, can you tell us where that stands at the present time?

Dr. Leung: The reason for not including it is primarily because of the inability to clone and better characterize that factor. There is still reason to believe that there may be such factors; however, the closest that has been really gotten to cloning an IgE-binding factor has been the soluble CD23 molecule that both Jan de Vries' group and Andy Saxon's group have shown induces IgE synthesis. Certainly, that molecule is very similar to the binding factors that we originally described, in the sense that it seems these IgE-binding factors are B-cell differentiation factors. They are certainly not like IL-4, in the sense that they are not isotypeswitch factors.

Dr. Hill: In our chronic granulomatous disease study, we used the drug three times a week. As I understand it, you used it every day in those patients. Was there a reason for doing that? And also, did you see any toxicity with the lower dose that you indicated that you used?

Dr. Leung: With the very lowest dose, $10 \mu \mathrm{g} / \mathrm{M}^{2}$, there is absolutely no toxicity. It was only at the 50 , and of course at the $100-\mu \mathrm{g}$ level, that $25 \%$ of the doses were associated with flu-like symptoms. Coming back to the issue of three times a week versus daily, I agree that one would have liked to have had even three arms in that study to look at that, and certainly that might be a basis for a phase IV trial. The reason for picking daily doses was really for statistical reasons. Based on the number of people entered, we had to pick some sort of a schedule. In this regard, the original open label study showed that even within $2 \mathrm{~d}$ of discontinuing IFN- $\gamma$ there was a tendency for a rebound in terms of worsening skin symptoms, as well as a rebound in IgE synthesis. That was our reason for deciding to go with the daily doses. But I agree there are patients even on prophylaxis now or maintenance who are doing pretty well at three times a week, and the issue is titrating the IFN- $\gamma$ dose.

Dr. Hill: Did you see neutropenia or lymphopenia developing at any time?

Dr. Leung: There was some, particularly in patients early on, but this was a reversible phenomenon. As they stayed on the IFN- $\gamma$ longer, in almost all cases their neutrophil counts went back to normal. Indeed, with the eosinophil data that I showed, we were concerned that maybe the reduction in eosinophils was due to this granulocytopenia effect, but in fact an analysis demonstrated no correlation between reduced white cell counts and reduction in eosinophil counts.

Dr. Ochs: Since you and Dr. Gelfand are now teamed up, what about teaming up IFN- $\gamma$ and IVIG (intravenous immune globulin)? We have for years heard Dr. Gelfand telling us that we should use IVIG in hyper-IgE syndromes and in asthmatic patients, and now you have an IFN- $\gamma$ that is reasonably well tolerated, and it works in some patients. Is it too much to ask you to do this kind of a study?

Dr. Leung: We have submitted a grant application to study this further. Let me just say that I think IFN- $\gamma$ is probably going in that direction, not to be used as an exclusive drug, but as an adjuvant or in combination with other drugs. I don't know if it will be used with IVIG because that works well alone. 
Dr. Gulati: Do you foresee any role for IVIG and IFN- $\alpha$ ?

Dr. Leung: There might be. The problem is that the companies who have IFN- $\alpha$ do not appear to be interested, at this time, in using it clinically in this setting, partly because there are more side effects from IFN- $\alpha$ than IFN- $\gamma$. One of the things I think that has not been well studied is whether patients who fail on doses of IFN- $\gamma$ at $50 \mu \mathrm{g} / \mathrm{M}^{2}$ might not do better on higher doses.

What we are looking at now is whether one can direct the cytokine therapy into particular organs to minimize side effects. As an example, Ron Crystal's group published a paper in the Journal of Clinical Immunology, in May 1991, showing the feasibility of nebulizing IFN- $\gamma$ into the lung. We are beginning to look at some trials along those lines, because when you nebulize IFN- $\gamma$ into the lung, you do not get the systemic side effects, even giving 10 times higher doses than we give subcutaneously.

Dr. Levinson: You have shown a lot of nice associations in terms of things working in the way we might like them to work, vis-à-vis with IFN- $\gamma$. The eosinophils are going down, but the total IgE isn't going down. But it is not clear to me that the effects that you are seeing are in fact mediated through $\mathrm{TH} 2$ cells or even through $\mathrm{T}$ cells themselves. Let me throw out another possibility for consideration. Several years ago, a dermatologist showed that if you treat patients with $\mathrm{AD}$ with erythromycin, they improve markedly because they are always colonized with staphylococci. Is it possible that all you are doing, in fact, is activating neutrophils to make them behave better, whereas they may not behave too well in the first place in AD? Maybe you are clearing staph or doing something that might not be too interesting to you as an immunologist but would certainly be interesting to you as a clinician.

Dr. Leung: Those are very interesting questions. We did superoxide generation studies and looked at neutrophil chemotaxis in AD patients treated with IFN- $\gamma$ versus placebo. There was no difference between the placebo and the IFN-treated group, although Harry Hill has certainly described the effects of IFN- $\gamma$ on neutrophil chemotaxis in the hypo-IgE syndrome. I think, like everything else, IFN- $\gamma$ is a pleiotropic drug. It is going to work on many factors. This, of course, was just a hypothesis.
Dr. Gelfand: With erythromycin, the interest is also as a macrolite antibiotic; it does have some effects on T cells, like troleandomycin, which is also like the cyclosporin FK5 or 6 effects. You may be modulating different cytokines.

Dr. Schiff: With your observations that the eosinophil count is going down, have you treated any patients with hyper-eosinophil syndrome or eosinophilofasciitis? Do you think it would have any role in these patients? I am particularly interested in production of IL-5. We are looking at that now in a couple of patients, trying to treat them by modulating $T$ cells rather than trying to use cytotoxic drugs.

Dr. Leung: We have not seen any hyper-eosinophil syndrome patients. The problem is that the disease itself is so rare that it would be hard to do a controlled trial to convince yourself you were seeing an effect. It would almost be anecdotal, but potentially it is worth trying on a case-by-case basis.

Dr. Schreiber: Following up on the comment about IFN- $\gamma$ effect on phagocytes, I want to suggest an experiment in terms of looking at chemotaxis or other factors. I think it is probably a more sensitive indicator. We have shown that very low doses of IFN- $\gamma$ will up-regulate at least two different $\mathrm{Fc}$ receptor gene products, one of which is a very potent mediator of a phagocytic signal in our hands. So I think that would be the direction to look at if you wanted to address that specifically.

Dr. Leung: There is a problem in $\mathrm{AD}$, and this is really a bias on my part, but when I was in Boston, we decided that since staph was so important in eczema, we would try a bacterial desensitization schedule, and actually try to introduce staph $502 \mathrm{~A}$ into the patients' flora. We found that when we gave them a regimen of Bactrim or rifampin, these patients would improve dramatically, but when we did staph counts, there was no change in the number of Staphylococcus aureus. So I suspect that part of it may even be modulation of the toxin production rather than enhanced phagocytosis or eradication of S. aureus. We have never personally been able to demonstrate any neutrophil defect, at least in $\mathrm{AD}$.

Dr. Schreiber: On the other hand, you can get up-regulation of a couple of receptors. Even though they might not be defective, they may perform much more effectively because you are dealing with an important regulatory molecule in that pathway. 